\title{
The Syllabus: A Place to Engage Students' Egos Mark Canada
}

This article originally appeared in New Directions for Teaching and Learning no. 135, Fall 2013

For many, a syllabus is the academic equivalent of an appliance manual. Everyone expects one, but reading it is another matter. A few compulsive sorts may pore over every letter. Others may refer to it only when there is a problem. Many may never look at it at all. A syllabus can be much more, however. A well-crafted syllabus can be the beginning of a promise fulfilled and part of the difference between just another course and one that changes lives.

Am I making too much of this simple document? Consider first the attitude that many students bring to their college courses. The author of one study of high school students has argued that the U.S. educational system tends to produce "robo-students" caught in the "grade trap." These students often wind up merely "doing school," developing strategies and even cheating to get the grades they believe they need to succeed in the larger world (Pope 2001, 4, 153-154). Furthermore, some researchers have suggested that Millennial students bring to their classes a sense of entitlement that constitutes, in Twenge's famous phrase, a "Generation Me" (Twenge et al. 2008; Greenberger et al. 2008). While such claims are by no means definitive (Trzesniewski and Donnellan 2008), there can be little doubt that the period of "emerging adulthood" is a "self-focused time of life" (Arnett 2007, 26). Many Millennial students, then, might evaluate opportunities with a direct question: "What's in it for me?"

Now, consider the role a syllabus can play in framing this opportunity. If students are asking, "What's in it for me?" the syllabus can provide compelling, inviting answers: self-discovery, a sense of fulfillment, and, yes, a better chance of succeeding in life, whatever "success" means to any given student. Through solid production and effective presentation of the syllabus, professors can engage Millennial students in a stimulating intellectual journey.

\section{Tone and Style}

If we want to craft a syllabus that will appeal to Millennial students' egos in productive ways, then we need to employ a style of plain language and a tone of friendliness and humility. 
Plain and Direct Language. A style of direct language is important. For instance, if many of today's students are focused on themselves, then one way to engage them in the syllabus may be as simple as using the pronoun you frequently. The constant use of "you" directly reminds students of their role in the course.

Furthermore, without plain language, Millennial students likely will experience the academic jargon of a course syllabus as verbose and meaningless - theoretical, paradigm, and empiricism are not part of their vernacular. We can and should teach students the necessary language of the discipline in the course, certainly; but first we need to engage them in the academic enterprise. A plain language style in the course syllabus will be more accessible and can help to ensure that the students will still be with us when it comes time to define the language of our discipline.

Friendliness. Research suggests that a friendly tone in a syllabus leaves students with more positive feelings toward the professor. In a study that called on them to read two syllabi-the first with a friendly tone and the second with a less friendly tone-students responded that the professor supposedly behind the first syllabus was warmer and more approachable than the professor supposedly behind the second syllabus (Harnish and Bridges 2011). In turn, students who find the professor approachable, we can assume, are more likely to seek assistance from this professor than they otherwise would be. Millennial students might be especially attracted to such a professor, who is more likely to be affirming than one who comes across as unfriendly in the syllabus. Giving a syllabus a friendlier tone can be as simple as adding a few personal or affirming phrases. For instance, instead of saying, "If you need to contact me," the "friendly" syllabus said, "I welcome you to contact me." Instead of referring to "skills you should obtain," this syllabus said, "skills I hope you will obtain" (Harnish and Bridges 2011, 323).

Humility. After years of study, professors naturally know far more about their subjects than their students know, but this gap in knowledge does not have to entail a gap in the relationship. In What the Best College Teachers Do, Bain (2004) notes that some outstanding professors come across as fellow intellectual sojourners in awe of the 
universe, not masters talking down to tenderfeet. One teacher even confessed his own difficulties with the material to his students. This humble approach helps to establish the relationship of professor and students as equals - on some level, anyway. Both are reasonably intelligent human beings with natural curiosities about the world. One has traveled quite a bit farther than the other, but both are on the same road and together can reach some of the same milestones. As long as the student appreciates what the professor has to offer- more knowledge and experience, if not necessarily more basic intelligence or human value - the resulting relationship can be positive. A humble syllabus says to students, "I'm with you. In fact, I used to be you."

\section{Conceptual Unity}

Of course, a syllabus is more than a warm or glitzy invitation to a course. For one thing, it should spell out the basics regarding assignments, deadlines, and grades. The syllabus also serves an important pedagogical role, framing the assignments and class work as part of "an organized and meaningful journey" (Slattery and Carlson 2005, 159). The inclusion of all these nuts and bolts, along with the unifying blueprint, need not render the syllabus lifeless. If the contents are carefully crafted to create conceptual unity, then a syllabus can engage students.

Syllabus Introduction. The introduction to the syllabus can promote the professor's confidence in students' abilities. Expressing confidence in students is a positive force in general (Bain 2004), and an introduction in the syllabus may be an appropriate place to express belief in each student's internal genius (Knowlton 2010). "Before we begin, let's get one thing straight," I say in the introductions to some of my syllabi. "I want to see every one of you succeed."

The introduction to a syllabus is also an ideal place to establish a "natural critical learning environment" (Bain 2004, 99), where students encounter large and meaningful questions that they will have the opportunity to explore throughout the course. Every discipline has such questions. For example, "What constitutes a good life?" and "What makes us love other people?" will come naturally in some philosophy 
and psychology syllabi. A syllabus in a math course might raise questions to help students see the content as more than a "plug and chug" series of formulas and equations, emphasizing instead its logic and rationality. Especially if they employ the word you-as in "Why do your parents make you so crazy?" - these questions can be especially useful in engaging Millennial students.

Finally, professors may want to use the introduction to establish a dramatic theme or inspiring metaphor for the course. By likening the course to an expedition or a project, professors not only add interest and make the material more accessible but also emphasize each student's role in his or her learning. Some professors, for example, characterize their students as "seekers" (Canada 2000, 35; Knowlton 2010, 78). Putting students in the driver's seat - or the captain's chair or the project manager's role, as the case may be-is sound pedagogy (Bain 2004). Here is the first paragraph of an introduction I use in a syllabus for a literature course:

Imagine a road trip that could take you all over America, showing you exotic locales, introducing you to interesting characters, and dropping you in the middle of wild adventures. You will set sail on the high seas, stalk through the wilds of Virginia, and stroll down the streets of Philadelphia. You will meet powerful leaders and oppressed slaves, pious Christians and fiendish villains. You will experience passionate love and abject terror. Best of all, you will return home not exhausted and defeated, but refreshed and enlightened.

Road trips, relationships, jobs, and sports are all useful metaphors, which can help move students from the worlds they know and value to the academic realm we are introducing to them.

Course Objectives. A natural follow-up to the introduction in the syllabus is a list of objectives for the course. Teachers already appreciate "critical thinking," "historical forces," and "scientific principles"; however, objectives phrased in these terms are not likely to resonate with Millennial students, at least not if presented without any reference to what they perceive as the real world, namely jobs, money, relationships, and personal interests (Adams 2005). 
The very notion that course objectives will center on learning is a key point, as it can help adjust the "consumer mentality" that leaves some students with the idea that courses are mere sources of credit hours or grades (O'Brien, Mills, and Cohen 2008). By simply helping students see how the learning in the course can help them with their own practical concerns, teachers can make a case for their courses. They might summarize studies showing that employers highly value communication skills or might articulate the value of "deep," "disciplinary," or "genuine" understanding (Bain 2004, 40; Gardner 1991, 9). Other possible approaches include encouraging students to set their own course goals (Lavoie 2007; Slattery and Carlson 2005).

Grading. Grades are the bane of any professor's existence. No one ever went into this profession to call balls and strikes, but umpires we are. While discussing grades in the syllabus is only fair, professors should take care to put them in perspective, explaining that grades are not ends in themselves, but merely an imperfect means for identifying successful learning. This approach might resonate with students who wish to be more learning-oriented (Pollio and Beck 2000). To minimize concern about grades, a professor might want to preface the description of the grading system with a statement like this one:

When you go to the gym, do you ask others to rate your form or give you a score for how much you can lift? When you play the piano, do you ask your family to write a review of your performance? If you're like me and most other people, you do such things because you enjoy them and want to improve, not because you are looking for a rating or a score. This course does involve grades; but when I assign those grades, I promise to do so conscientiously, applying the standards and criteria that are listed in this syllabus. Through this approach, the grade that you earn should provide an indication of my judgments about your learning.

Such a statement not only puts the emphasis on the learning and not the grades but also assures students that grades will be based on meaningful criteria - a useful message for students who suspect that 
knowledge is really a matter of opinion (Lippmann, Bulanda, and Wagenaar 2009). As the passage implies, professors can further combat this suspicion by making sure that the standards and criteria are stated clearly in the syllabus. Professors also should build assignments into the grading section of the syllabus that proclaim the importance of students applying the criteria and standards to their own work as a selfevaluation. Including this in the syllabus can help combat Adams's (2005) concern that students sometimes put more emphasis on effort than professors do. Promoting self-evaluation in the syllabus provides opportunities to think beyond effort alone.

\section{Creating Early-Semester Engagement with the Syllabus}

Even the best syllabus is worthless to the student who never reads it. While professors cannot force students to read anything, they can encourage them to engage with the syllabus, just as they would ask students to engage with a poem or an academic argument. Deep engagement will help students absorb the messages within the syllabus. For starters, professors can take a few minutes to walk students through the syllabus on the first day of class, taking care to complement its messages about big questions and promises with their oral remarks, expressions, gestures, and tone of voice.

Professors could ask students to begin weighing in on the big questions, first on paper and then out loud with others in the class. A brief writing assignment can extend the reflection outside the class, giving students an additional opportunity to reflect on the objectives and assignments described in the syllabus. For instance, biology professors might ask students to respond in writing to a question like this one: "How do you foresee using your knowledge of biology in your career, hobbies, or personal life?" In this way the assignment can call on students to move from the syllabus to some personal goals (Slattery and Carlson 2005). This type of assignment early in the semester can serve as a point for reflection and growth monitoring throughout the semester, thereby emphasizing the role of the syllabus as something other than a static document. 


\section{Conclusion}

Business professionals know the power of the executive summary. Lawyers spend hours carefully crafting the opening statement. Conductors detail every nuance of the overture. It is time that professors take full advantage of their first written contact with students. Whatever its reputation, the syllabus need not be an opportunity wasted. A syllabus that is well crafted and meaningfully presented can shift the Millennial students' question from "What's in it for me?" to "What role should I play in discovering what's in it for me?" 


\section{References}

Adams, J. B. 2005. "What Makes the Grade? Faculty and Student Perceptions." Teaching of Psychology 32 (1): 21-24.

Arnett, J. J. 2007. "Suffering, Selfish, Slackers? Myths and Reality about Emerging Adults." Journal of Youth and Adolescence 36: 23-29.

Bain, K. 2004. What the Best College Teachers Do. Cambridge, MA: Harvard University Press.

Canada, M. 2000. "Students as Seekers in Online Courses." In Principles of Effective Teaching in the Online Classroom, edited by R. E. Weiss, B. W. Speck, and D. S. Knowlton, 35-40. San Francisco: Jossey-Bass.

Gardner, H. 1991. The Unschooled Mind: How Children Think and How Schools Should Teach. New York: Basic Books.

Greenberger, E., J. Lessard, C. Chen, and S. P. Farruggia. 2008. "SelfEntitled College Students: Contributions of Personality, Parenting, and Motivational Factors." Journal of Youth and Adolescence 37 (10): 1192-1204.

Harnish, R. J., and K. R. Bridges. 2011. "Effect of Syllabus Tone: Students' Perceptions of Instructor and Course." Social Psychology of Education 14 (3): 319-330.

Knowlton, D. S. 2010. "Take Out the Tests, and Hide the Grades; Add the Spiritual with All Voices Raised! Professor Explications and Students' Opinions of an Unconventional Classroom Milieu." Critical Questions in Education 1 (2): 70-93.

Lavoie, R. 2007. The Motivation Breakthrough: 6 Secrets to Turning on the Tuned-Out Child. New York: Touchstone.

Lippmann, S., R. Bulanda, and T. Wagenaar. 2009. "Student Entitlement." College Teaching 57 (4): 197-204.

O'Brien, J. G., B. J. Mills, and M. W. Cohen. 2008. The Course Syllabus: A Learning-Centered Approach. San Francisco: Jossey-Bass. Pollio, H. R., and H. P. Beck. 2000. "When the Tail Wags the Dog: Perceptions of Learning and Grade Orientation in, and by, Contemporary College Students and Faculty." Journal of Higher Education 71 (1): 84-102.

Pope, D. C. 2001. Doing School: How We Are Creating a Generation of Stressed Out, Materialistic, and Miseducated Students. New Haven, 
CT: Yale University Press.

Slattery, J. M., and J. F. Carlson. 2005. "Preparing an Effective Syllabus: Current Best Practices." College Teaching 53 (4): 159-164.

Trzesniewski, K. H., and M. B. Donnellan. 2008. "Is 'Generation Me' Really More Narcissistic Than Previous Generations?" Journal of Personality 76 (4): 903-918.

Twenge, J. M., S. Konrath, J. D. Foster, W. K. Campbell, and B. J. Bushman. 2008. "Egos Inflating over Time: A Cross-Temporal Metaanalysis of the Narcissistic Personality Inventory." Journal of Personality 76: 875-901. 